\title{
PENTINGNYA PEMBELAJARAN MULTILITERASI UNTUK MAHASISWA PENDIDIKAN GURU SEKOLAH DASAR DALAM MEMPERSIAPKAN DIRI MENGHADAPI KURIKULUM 2013
}

\author{
Esti Untari \\ e-mail:taries07@gmail.com \\ PP3 Jl. Ir Soekarno No.1, FIP, Universitas Negeri Malang
}

\begin{abstract}
Abstrak: Penerapan kurikulum 2013 menekankan peningkatan dan keseimbangan soft skill dan hard skill. Mahasiswa Pendidikan Guru Sekolah Dasar sebagai calon pendidik generasi penerus harus memiliki kemampuan individual untuk mengkombinasikan dan mengkoordinasikan kegiatan pembelajaran yang dapat membuat siswa aktif dalam belajar. Pembelajaran multiliterasi merupakan pembelajaran yang dikembangkan dengan berbasis kerja ilmiah. Pembelajaran ini bertujuan untuk membentuk siswa yang siap dari berbagai segi dalam menjalani kehidupan baik di sekolah, tempat kerja dan masyarakat.Pembelajaran Multiliterasi perlu diterapkan untuk mahasiswa PGSD sehingga mahasiswa memiliki keterampilan untuk dapat melaksanakan pembelajaran dalam menerapkan kurikulum 2013 dengan baik.
\end{abstract}

Kata Kunci: kurikulum 2013, pembelajaran mulitiliterasi, mahasiswa PGSD

Kurikulum digunakan pertama kali pada dunia olahraga pada zaman Yunani kuno yang berasal dari kata curir dan curere. Kurikulum mengalami perubahan sesuai dengan berkembangnya zaman. Di Indonesia, kurikulum sudah mengalami perubahan beberapa kali. Kurikulum di Indonesia diberi nama sesuai dengan tahun mulai berlakunya. Tahun 1950 ada kurikulum SD yang disebut "Rencana Pelajaran Terurai". Pada tahun 1960 muncul "Kurikulum Kewajiban Belajar Sekolah Dasar". Tahun 1968 dikenal "Kurikulum 1968" pengganti "Kurikulum 1950". Lalu tahun 1970 muncul "Kurikulum Berhitung" diganti dengan pelajaran matematika modern. Tahun 1975 disebut "Kurikulum 1975" yang fokus pada pelajaran matematika dan Pendidikan Moral Pancasila serta Pendidikan Kewarnegaraan. Pada tahun 1984 menyempurnakan Kurikulum 1975 dengan "Cara Belajar Siswa Aktif” (CBSA). Tahun 1991 CBSA dihentikan lalu muncul "Kurikulum
1994". Tahun 2004 dikenal "Kurikulum Berbasis Kompetensi" (KBK). Tahun 2006 muncul "Kurikulum Tingkat Satuan Pendidikan" (KTSP). Terakhir tahun 2013 yang disebut dengan "Kurikulum 2013"

Perubahan kurikulum ini mempunyai dasar yang jelas. Perubahan ini untuk memperbaiki dan mengembangkan kurikulum sebelumnya sehingga meningkatkan kualitas pendidikan nasional. Pendidik dan tenaga kependidikan dituntut siap dalam mengimplementasikan kurikulum 2013. Mahasiswa PGSD merupakan calon pendidik yang perlu diberikan bekal dalam menghadapi kurikulum yang selalu berubah. Salah satunya dengan pembelajaran multiliterasi. Proses pembelajaran multilireasi diharapkan peserta didik memiliki keterampilan multiliterasi. Keterampilan multiliterasi yang harus dikuasai agar mampu mendukung dan mengembangkan kompetensi-kompetensi tersebut meliputi keterampilan membaca pemahaman yang tinggi, 
keterampilan menulis yang baik untuk membangun dan mengekspresikan makna, keterampilan berbicara secara akuntabel, dan keterampilan menguasai berbagai media digital. Keterampilan tersebut dibutuhkan mahasiswa dalam mengimplementasikan kurikulum 2013.

\section{Kurikulum 2013}

Kurikulum 2013 merupakan kurikulum yang menyempurnakan kurikulum yang telah ada. Dalam kurikulum 2013 untuk jenjang SD/ MI proses pembelajaran menerapkan pembelajaran tematik terpadu. Ciri pembelajaran ini berpusat pada peserta didik dengan memberikan pengalaman langsung, bersifat luwes, dan hasil pembelajaran dapat berkembang sesuai dengan minat serta kebutuhan peserta didik. Pembelajaran tematik terpadu memiliki sifat memandu peserta didik mencapai kemampuan berpikir tingkat tinggi (higher levels of thinking) atau keterampilan berpikir dengan mengoptimasi kecerdasan ganda (multiple thinking skills).

Kurikulum 2013 adalah pengembangan dari kurikulum yang sudah ada yaitu Kurikulum Berbasis Kompetensi dan Kurikulum Tingkat Satuan Pendidikan. Kurikulum 2013 menekankan pada peningkatan dan keseimbangan soft skill dan hard skill yang meliputi aspek kompetensi sikap, pengetahuan, dan ketrampilan. Kedudukan kompetensi yang semula diturunkan dari mata pelajaran, berubah menjadi mata pelajaran dikembangkan dari kompetensi.

Undang-undang No. 20 Tahun 2003 tentang Sistem Pendidikan Nasional menyebutkan bahwa fungsi kurikulum ialah mengembangkan kemampuan dan membentuk watak serta peradaban bangsa yang bermartabat dalam mencerdaskan kehidupan bangsa. Sedangkan tujuan kurikulum menurut UndangUndang No. 20 Tahun 2003 adalah untuk mengembangkan potensi siswa agar menjadi manusia yang beriman dan bertaqwa kepada Tuhan Yang Maha Esa, Berakhlak mulia, sehat, berilmu, cakap, kreatif, mandiri, dan menjadi warga negara yang demokratis serta bertanggung jawab. Tujuan Kurikulum 2013 menurut Fadlilah (2014:25) yaitu :1) Meningkatkan mutu pendidikan dengan menyeimbangkan hard skill dan soft skill melalui kemampuan sikap, keterampilan dan pengetahuan dalam rangka menghadapi tantangan global yang terus berkembang. 2) Membentuk dan meningkatkan sumberdaya manusia yang produktif, kreatif, dan inovatif sebagai modal pembangunan bangsa dan negara Indonesia. 2) Kurikulum 2013 mempunyai karakteristik atau ciri khas yang membedakan dengan kurikulum-kurikulum sebelumnya. Karakteristik tersebut adalah sebagai berikut:

\section{Pendekatan pembelajaran}

Pendekatan yang digunakan dalam pembelajaran Kurikulum 2013 adalah pendekatan saintifik dan tematik integratif. Pembelajaran dengan pendekatan saintifik dilakukan dengan proses ilmiah. Dalam hal ini apa yang diperoleh siswa dilakukan dengan indra dan akal pikiran sendiri sehingga mereka mengalami secara langsung dalam proses mendapatkan ilmu pengetahuan. Pembelajaran menggunakan pendekatan saintifik dilakukan melalui proses mengamati, menanya, mencoba, menalar, dan mengkomunikasikan. Pembelajaran seperti ini dimaksudkan untuk meningkatkan dan membentuk sikap ketrampilan, dan pengetahuan siswa secara maksimal.

Pendekatan tematik terintegrasi pembelajaranya dibuat pertema dengan mengacu karakteristik siswa dan dilaksanakan secara integrasi antara tema satu dengan tema yang lain maupun antara mata pelajaran satu dengan mata pelajaran yang lain. Hal ini bertujuan agar terjadi keterpaduan yang seimbang, sehingga dihasilkan lulusan yang memiliki sikap, pengetahuan, dan ketrampilan yang memadai sebagai bekal untuk menghadapi tantangan di masa mendatang.

\section{Kompetensi Lulusan}

Kompetensi lulusan pada kurikulum 2013 berhubungan dengan kompetensi sikap, keter- 
ampilan, dan pengetahuan. Kompetensi-kompetensi tersebut sebenarnya sudah ada pada kurikulum sebelumnya, hanya penyebutanya yang berbeda. Penyebutan kompetensi sikap dalam KTSP adalah afektif, pengetahuan disebut kognitif dan keetrampilan disebut psikomotorik. Perbedaannya adalah titik tekannya, yaitu pada kurikulum KTSP menekankan pada pengetahuan (kognitif), sedangkan pada kurikulum 2013 lebih mengutamakan kemampuan sikap (afektif).

Ketiga kompetensi tersebut diperoleh melalui proses yang berbeda. Fadlilah (2014:178)" sikap diperoleh melalui aktivitas menerima, menjalankan, menghargai, menghayati, mengamalkan. Kompetensi pengetahuan diperoleh melalalui aktivitas mengingat, memahami, menerapkan, menganalisis, mengevaluasi. Ketrampilan diperoleh melalui aktivitas mengamati, menanya, mencoba, menalar, menyaji, dan mencipta". Kompetensi sikap, pengetahuan dan ketrampilan yang berjalan secara seimbang diharapkan dapat membekali siswa dengan hard skill dan sft skill yang mumpuni. Kemampuan ini akan menjadi bekal siswa meraih keberhasilannya di masa depan.

\section{Penilaian}

Penilaian pembelajaran pada kurikulum 2013 menggunakan penilaian autentik. Penilaian autentik adalah penilaian yang dilakukan secara menyeluruh, meliputi persiapan siswa, proses pembelajaran, dan hasil belajar siswa. Penilaian ini membantu guru untuk mengetahui pencapaian siswa yang meliputi sikap, pengetahuan, dan ketrampilan. Masing-masing kompetensi memiliki instrumen penilaian masing-masing.

\section{Mahasiswa Pendidikan Guru Sekolah Dasar}

Mahasiswa Pendidikan Guru Sekolah Dasar, salah satu seorang generalis, terspesialisasi dalam kemahirannya di salah satu bidang. Mahasiswa PGSD menjadi tonggak perbaikan bangsa karena menyiapkan generasi muda penerus negara ini. Seorang guru SD akan memajukan pendidikan di Indonesia dan membentuk kepribadian anak yang baik serta ikhlas dalam mengabdikan diri demi kemajuan anak. Guru sekolah dasar yang mampu merancang dan melaksanakan pembelajaran di sekolah dasar yang mengaktifkan siswa dengan kegiatan yang bermakna untuk mencapai tujuan pembelajaran di SD yang meliputi penguasaan lima mata pelajaran pokok (Bahasa Indonesia, Matematika, Pendidikan Kewarganegaraan, Ilmu Pengetahuan Sosial, dan Ilmu Pengetahuan Alam serta mampu mengembangkan mata pelajaran pendukung lainnya.

Program studi Pendidikan Guru Sekolah Dasar memberikan bekal kepada mahasiswa untuk siap tidak hanya mengajar tetapi juga mendidik anak-anak bangsa, sehingga dalam proses pembelajarannya diharapkan mahasiswa mampu mengembangkan seluruh potensi yang dimilikinya. Seiring dengan perkembangan teknologi saat ini dan pembaharuan kurikulum seorang mahasiswa khususnya PGSD, harus siap dan selalu mengikuti perkembangan pengetahuan.

\section{Pembelajaran Multiliterasi}

Istilah literasi didefinisikan sebagai kemampuan memahami simbol-simbol bahasa atau kemampuan keaksaraan. Berdasarkan cakupan awalnya, literasi dipandang sebagai kondisi melek huruf, melek kata dan melek makna. Dalam perkembangannya, literasi yang digunakan dalam berbagai bidang ilmu tersebut menggunakan berbagai media sebagai alat komunikasi dan pembentukan makna. Upaya penyampaian informasi bisa dilakukan melalui berbagai media sehingga tulisan tidak bisa dibatasi hanya sekedar tata bahasa linguistik melainkan melewati batas-batas tata bahasa lingustik. Pandangan ini kemudian melahirkan istilah metabahasa, teks multimodal, dan akhirnya berujung pada konsep multiliterasi 


\section{Konsep Multiliterasi}

Baguley, Pullen dan Short (2010), memandang multiliterasi sebagai cara untuk memahami secara lebih luas kurikulum literasi yang dipelajari di sekolah formal yang mendorong siswa agar mampu berpartisipasi secara produktif di dalam komunitas masyarakat. Secara konseptual multiliterasi merupakan sebuah ancangan yang dapat digunakan untuk memahami beragam jenis teks dan beragam bentuk media yang dihasilkan berbagai teknologi baru melalui konsep pedagogi yang memberikan guru untuk menyajikan informasi kepada siswa dengan menggunakan beragam bentuk teks dan media.

The New London Group (2005) menyatakan bahwa pedagogi multiliterasi dibangun oleh empat komponen atau proses pengetahuan yakni situasi praktis, pembelajaran yang jelas, bingkai kritis, dan transformasi praktis. Cope dan Kalantzis (2005) lebih lanjut menyatakan bahwa keempat komponen ini merupakan satu kesatuan utuh yang saling memperkuat satu sama lain dan menyajikan sebuah pengalaman belajar efektif dan efisien.

Berdasarkan pemikiran tersebut multiliterasi berkenaan dengan multikonteks, multimedia, dan multibudaya. Multikonteks, keterampilan ini tidak hanya berkenaan dengan salah satu konteks melainkan beragam konteks baik konteks situasi maupun konteks keilmuan. Konteks situasi merupakan konteks di luar teks yang dapat digunakan untuk memahami isi teks. Konteks kelimuan berarti bahwa teks yang dipelajari merupakan teks yang tidak hanya merujuk pada berbagai bidang ilmu, sehingga keterampilan multiliterasi bersifat lintas disiplin ilmu atau lintas kurikulum.

Multimedia, hal ini berarti literasi bukan hanya dipelajari menggunakan salah satu jenis media tetapi beragam media baik secara konvensional maupun media digital. Selain itu multiliterasi juga berkenaan dengan multibudaya, konsep ini sejalan dengan konsep literasi kritis yang memandang sebuah teks tidak bersifat tunabudaya. Sebuah teks yang disusun dipengaruhi oleh disposisi penulisnya terhadap dimensi-dimensi budaya tertentu.

Berdasarkan konsep multiliterasi diatas, pembelajaran multiliterasi merupakan pembelajaran yang dikembangkan atas dasar komponen-komponen dasar multiliterasi. Pembelajaran ini dikembangkan atas dasar keberagaman kemampuan siswa baik dari sisi kecerdasan, gaya belajar maupun modal belajarnya.

\section{Pembelajaran Multiliterasi}

Pembelajaran multiliterasi terarah pada multikompetensi. Dalam pembelajaran multiliterasi, siswa tidak hanya memperoleh satu kompetensi melainkan beragam kompetensi sikap dan karakter. Kompetensi yang dimiliki meliputi kompetensi pemamhaman yang tinggi, kompetensi berpikir kritis, kompetensi berkolaborasi dan berkomunikasi, serta kompetensi berpikir kreatif. Pembelajaran ini bertujuan untuk membentuk siswa yang siap dari berbagai segi dalam menjalani kehidupan baik di sekolah, tempat kerja dan masyarakat.

Menurut Morocco, et al. (2008: 10), Keterampilan-keterampilan multiliterasi yang harus dikuasai agar mampu mendukung dan mengembangkan kompetensi-kompetensi tersebut meliputi keterampilan membaca pemahaman yang tinggi, keterampilan menulis yang baik untuk membangun dan mengekspresikan makna, keterampilan berbicara secara akuntabel, dan keterampilan menguasai berbagai media digital.

Pembelajaran multiliterasi dipandang memiliki beberapa karakteistik yang dikemukakan Olge, et.al (2007) sebagai berikut: 1) Pembelajaran multiliterasi senantiasa menghubungkan materi yang dipelajari dengan apa yang telah siswa ketahui. 2) Pembelajaran multiliterasi senantiasa menghubungkan materi yang dipelajari dengan kehidupan nyata dan isu-isu kontemporer. 3) Pembelajaran multiliterasi senantiasa melibatkan siswa untuk terlibat aktif dalam mengajukan pertanyaan dan membuat simpulan sendiri. 4) Pembelajaran multiliterasi memberikan banyak peluang un- 
tuk mempelajari materi pembelajaran secara mendalam sekaligus menyimpan pemahaman yang diperoleh dalam memori jangka panjang siswa . 5) Pembelajaran multiliterasi senantiasa menggunakan kerja kolaboratif dalam mengontruksi makna dan sudut pandang atas materi yang sedang dipelajari. 6) Pembelajaran multiliterasi meibatkan berbagai ragam belajar sebagai sarana mengontruksi pemahaman baru. 7) Pembelajaran multiliterasi melibatkan banyak strategi belajar.

\section{Siklus Pembelajaran Multiliterasi}

Pembelajaran multiliterasi merupakan pembelajaran yang dikembangkan dengan berbasis kerja ilmiah. Oleh sebab itu, salah satu komponen dalam pembelajaran multiliterasi adalah siklus belajar atau siklus pembentukan makna. Siklus ini merupakan panduan bagi keterlaksanaan pembelajaran literasi di dalam kelas. Tahapan siklus pembelajaran literasi yang dikemukakan oleh Morocco (2008: 27) sebagai berikut: 1) Melibatkan, pembelajaran melibatkan siswa dengan menggali pengetahuan awal yang dimiliki.. 2) Merespons, kegiatan untuk merespons seluruh tantangan belajar yang diberikan guru. Siswa secara aktif melakukan berbagai penyelidikan, observasi ataupun kegiatan penelitian sederhana untuk menjawab pertanyaan yang diberikan pada tahap pertama. 3) Elaborasi, siswa mengelaborasi berbagai temuan individu dan kelompok dan menuangkan dalam bentuk laporan.. 4) Meninjau ulang, laporan sementara ditinjau ulang dan mempersiapkan untuk menyampaikan hasil dalam diskusi kelas. 5) Mempresentasikan, perwakilan kelompok mempresentasikan hasil kerja, dilajutkan kegiatan peninjauan, penguatan dan pengembangan materi oleh guru.

\section{Pentingnya Pembelajaran Multiliterasi Bagi Mahasiswa PGSD}

Pada zaman yang serba digital ini pembelajaran yang dikembangkan atas dasar keberagaman kemampuan siswa baik dari sisi kecerdasan, gaya belajar maupun modal be- lajarnya. Metode, media serta strategi harus juga dikembangkan dengan menggunakan teknologi. Begitu pula dengan Kurikulum 2013 yang lebih menekankan pada aktivifitas siswa dalam pembelajaran sehingga pembelajaran multiliterasi ini sangat tepat diterapkan untuk Mahasiswa PGSD, sebagai bekal untuk mengajar untuk generasi masa datang yang lebih baik.

Salah satu contoh hasil studi PISA tahun 2000/2001 dan 2003, kemampuan literasi sains siswa Indonesia pada tahun 2006 relatif stabil atau tidak mengalami peningkatan. Skor literasi sains rata-rata siswa Indonesia pada tahun 2000/2001 adalah 393 dan tahun 2003 adalah 395. Hasil studi PISA tahun 2009 menunjukkan tingkat literasi sains siswa Indonesia yang tidak jauh berbeda dengan hasil studi tahun 2006. Tingkat literasi sains siswa Indonesia berada pada peringkat ke 57 dari 65 negara peserta dengan skor yang diperoleh 383 dan skor ini berada di bawah rata-rata standar dari PISA(OECD, PISA2009 Database). Hasil tersebut sangat memprihatinkan dibandingkan dengan negara berkembang lainnya, karena sistem pendidikan di Indonesia menggunakan kurikulum yang menekankan hafalan semata.

Seiring dengan perkembangan zaman dan teknologi pemerintah melakukan pembaharuan pendidikan dengan menerapkan kurikulum 2013, dimana dalam kurikulum ini metode yang digunakan menuntut siswa untuk aktif. Kurikulum 2013 lebih menekankan pembelajaran yang lebih komplek dan mengarah pada pendekatan literasi. Sehingga dengan kurikulum 2013, diharapkan kemampuan literasi siswa meningkat.

\section{Penelitian Tentang Literasi}

Beberapa hasil penelitian tentang literasi yang telah diteliti, berikut hasil analisis studi yang relevan

Berdasarkan hasil penelitian di atas bahwa kemampuan literasi sebagian besar siswa di Indonesia masih relatif rendah sehingga dengan pembelajaran multiliterasi akan meningkatkan kemampuan literasi siswa, ka- 


\section{Tabel 1. Analisis Studi yang Relevan dengan penelitian tentang literasi}

\begin{tabular}{|c|c|c|c|}
\hline $\begin{array}{l}\text { Peneliti \& } \\
\text { Tahun }\end{array}$ & Subjek & $\begin{array}{l}\text { Kemampuan yang } \\
\text { diteliti }\end{array}$ & Hasil Penelitian \\
\hline $\begin{array}{l}\text { B e } n \text { i a t i } \\
\text { Lestyarini, } 2011\end{array}$ & $\begin{array}{l}\text { M a h a s is w a } \\
\text { P e n d i d i a n } \\
\text { Sastra Bahasa } \\
\text { Indonesia }\end{array}$ & $\begin{array}{l}\text { Kemampuan menulis } \\
\text { mahasiswa pendidikan } \\
\text { sastra bahasa Indonesia }\end{array}$ & $\begin{array}{l}\text { Assemen autentik dalam } \\
\text { Pembelajaran multiliterasi } \\
\text { di kelas menulis dapat } \\
\text { meningkatkan kreatifitas, } \\
\text { inovatif dan membuat } \\
\text { pembelajaran menyenangkan }\end{array}$ \\
\hline $\begin{array}{l}\text { Mahdiansyah } \\
\text { dan Rahmawati, } \\
2014\end{array}$ & Siswa SMA & $\begin{array}{l}\text { Kemampuan literasi } \\
\text { matematika siswa SMA }\end{array}$ & $\begin{array}{l}\text { Kemampuan literasi siswa } \\
\text { jenjang menengah relatif } \\
\text { rendah, dan hasil tes literasi } \\
\text { kemampuan literasi tiap daerah } \\
\text { bervariasi }\end{array}$ \\
\hline $\begin{array}{l}\text { Abdul latip } \\
\text { dan Anna } \\
\text { Permanasari, } \\
2015\end{array}$ & Siswa SMP & $\begin{array}{l}\text { E f e } k \text { t i f i t a } s \\
\text { p e m b e l a j a } r \text { a } n \\
\text { berbasis } \\
\text { dengan menggunakan } \\
\text { multimedia }\end{array}$ & $\begin{array}{ll}\text { Penggunaan } & \text { multimedia } \\
\text { berbasis literasi } & \text { sains dapat } \\
\text { meningkatkan } & \text { kemampuan } \\
\text { literasi siswa } & \end{array}$ \\
\hline
\end{tabular}

rena pembelajaran ini mempunyai karakteristik melibatkan siswa secara langsung, menekankan berbasis kerja ilmiah.

\section{SIMPULAN DAN SARAN}

Mahasiswa Pendidikan Guru Sekolah Dasar, adalah salah satu calon pendidik yang diharapkan mampu membentuk calon penerus bangsa yang memiliki kompetensi (kognitif), sikap (afektif), keterampilan (psikomotorik). Pentingnya kemampuan mahasiswa dalam pembelajaran multiterasi dalam menghadapi perubahan kurikulum khususnya kurikulum 2013 menjadi bekal sebagai tenaga pendidik yang memilki standart kompetensi tinggi. Sebagai calon tenaga pendidik kedepannya mahasiswa lulusan PGSD mampu menyesuaikan berbagai perubahan pola kurikulum dengan bekal materi pembelajaran multiterasi yang telah diterima selama perkuliahan.

Pembelajaran multiliterasi harus dikembangkan terus dikalangan mahasiswa PGSD melalui berbagai jalur seperti penelitian lanjutan terkait pembelajaran multiliterasi. Penelitian yang berkelanjutan dapat menemukan berbagai formula metode pembelajaran yang dapat dipahami mahasiswa PGSD secara sederhana. Pembentukan FGD (Focus Group
Disscusion) dikalangan mahasiswa PGSD dalam menelaah pembelajaran multilierasi didalam kurikulum 2013 diluar jam perkuliahan. Dosen dan pihak kampus menjadi pendamping dan pembimbing dalam proses FGD dengan membuat fasilitas Laboratorium Lapangan sebagai aktualisasi praktikum mahasiswa.

\section{DAFTAR RUJUKAN}

Abdul latip dan Anna Permanasari. 2015. Pengembangan Multimedia Pembelajaran Berbasis Literasi Sains Untuk Siswa SMP Pada Tema Teknologi. Bandung: Prosiding Simposium Nasional Inovasi dan Pembelajaran Sains 2015

Beniati Lestyarini. 2011. Asesmen Autentik Dan Relevansinya Di Era Multiliterasi. Makalah Yogyakarta: Universitas Negeri Yogyakarta

Fadlillah, M. 2014. Implementasi Kurikulum 2013 Dalam Pembelajaran SD/MI. SMP/ $M t s, \quad \& S M A / M A$. Yogyakarta: Ar-Ruzz Media

Kemendikbud.2014. Permendikbud No. 103 tahun 2014 tentang Pembelajaran Pada Pendidikan Dasar dan Pendidikan Menengah. Kemendikbud : Jakarta 
Permendikbud No. 104 tahun 2014 tentang Penilaian Hasil Belajar Oleh Pendidik pada Pendidikan Dasar dan Pendidikan Menengah. Jakarta : Kemendikbud

Mahdiansyah dan Rahmawati. 2014. Literasi Matematika Siswa Pendidikan Menengah:Analisis Menggunakan Desain Tes Internasional dengan Konteks Indonesia. Jakarta : Balitbang Kemendikbud
Mulyasa, E. 2013. Pengembangan dan Implementasi Kurikulum 2013. Bandung: PT. Remaja Rosdakarya

Sukmadinata,Nana Syaodih. 1997. Pengembangan Kurikulum:Teori Dan Praktik. Bandung:PT. Remaja Rosdakarya Yunus Abidin, Tita Mulyati dan Hana Yunansah. 2015. Pembelajaran Literasi. Bandung: Rizqi Press

Yunus Abidin, dkk. Pembelajaran Multiliterasi. Bandung: PT. Refika Aditama 